\title{
Predicting Teachers' Familiarity on High Order Thinking Skills through Common Keywords in Science Learning: A Preliminary Study
}

\author{
Erman Erman $^{1}$, Nur Wakhidah ${ }^{2}$ \\ \{erman@unesa.ac.id ${ }^{1}$, nurwakhidah@uinsby.ac.id $\left.{ }^{2}\right\}$ \\ Science Education Department, FMIPA, Universitas Negeri Surabaya ${ }^{1}$, Science Education, \\ Universitas Islam Negeri Sunan Ampel Surabaya ${ }^{2}$
}

\begin{abstract}
This study aims to predict science teachers' familiarity in high order thinking skills (HOTS). There were 44 members of the science teacher community who volunteered to participate in this study. The data were collected using some common keywords in science learning in the form of multiple-choice tests, questioner, and its analyzed descriptively using content analysis. Data analysis results showed that: 1) more than half of the teachers were not familiar with HOTS, although they had often heard the terms, 2) conceptually, less than 50\% of teachers were familiar with the type of HOTS, but they were quite familiar with its application in learning, and 3) teachers were quite familiar with terms related HOTS in classroom, but still have difficulty to explain the learning that stimulates the student. Thinking of HOTS it's not sufficient to be just familiar with the term, but it should be applying its sustainably.
\end{abstract}

Keywords: Commonly keywords, Hots familiarity, Science teacher

\section{Introduction}

The term of high order thinking skills has been known in the context of natural science education. Generally, Indonesian teachers have used Bloom's taxonomy to determine cognitive levels that are expected to be achieved by students when design learning activities. However, many students are found experiencing difficulties in learning science in terms of their cognitive levels [1-4] and lack of HOTS [5]. These learning difficulties indicating Bloom's taxonomy in science learning is not optimally implemented. The taxonomy implementation in science classrooms requires further study to stimulate students' thinking abilities including giving critical questions [4] and learning settings [1].

Bloom's taxonomy contains 6 cognitive levels that are $\mathrm{C} 1$ level (knowledge) which is often referred to as rote knowledge, C2 level (understanding), C3 level (applying), C4 level (analyzing), C5 level (evaluating), and C6 level (creating). The first three levels are often categorized as low order thinking skills (LOTS), while the top three levels are called high order thinking skills (HOTS). In the classroom, LOTS is achieved and operated by students easier than HOTS. HOTS is complex and is not easy to define in the classroom [6]. Generally, the educators and the science teachers have hoped their students are able to achieve and operate HOTS levels during the classroom. HOTS is not only needed to learn in science, but also in lives [9]. Unfortunately, many students are found to have difficulty to reach and operate HOTS [4]. 
Many studies, such as: [3], [7-13], found that students' thinking ability, including HOTS, does not develop naturally, but requires the intensive training. Students were supposed to have difficulty using HOTS have never been trained to think HOTS due to teacher's inability to think HOTS [12]. The teacher has an important role in developing students' thinking abilities. This role will be performed in the classroom if the teacher has the ability to think HOTS and has adequate knowledge about HOTS.

In the application of a new curriculum (K13) in Indonesia, HOTS fundamentally were involved in the classroom. In such learning, students will be at least to conduct data analysis and/or critical thinking. By scientific approach, science learning begins with observing a phenomenon or object that triggers questions or problems that are needed in conducting an investigation or experiment. Thus, HOTS is probably most familiar to the science teachers. However, teachers were found unable to explain HOTS conceptually including its definition [14]. Science teachers were found mistakes when performing HOTS in their classrooms [12]. Thus, it could be assumed that teachers were unable to apply HOTS in their classroom. teachers' familiarity with HOTS in the learning settings is urgently to discover. Teachers' role is essential in developing students' higher-order thinking skills [15],[16].

\section{Method}

This study used a survey research design to predict teachers' familiarity with HOTS by using some common keywords that were often involved in the classroom. A total of 44 teachers who are members of the Science Teachers' Consultative Group (MGMP) in a district in East Java have voluntarily participated in this study.

Data collection was carried out in two stages, namely the giving of a HOTS familiarity test and the giving of a questionnaire to clarify the results of a familiarity test. The HOTS familiarity test consists of 10 items in the form of multiple choices to address teachers' familiarity with HOTS both concept and its application in the classroom. Five keywords which are high order thinking skills, questions, learning activities, competences to perform HOTS, and giving examples of HOTS were used to address teachers'familiarity with HOTS concepts. In its' application, we also used 5 common keywords which are model of learning, learning initiation, learning activities including science experiments, questioning, and ending a learning process. We also carried out using a questionnaire consist of 5 questions to clarify the teacher's answers on the HOTS familiarity test. The questionnaire includes learning models that are often used by teachers in learning science which are the HOTS in science learning, training HOTS experiences, HOTS examples of curriculum, and students'assignments to trigger HOTS among students.

Data were analyzed descriptively using content analysis of each teacher's answers, tests, and questionnaires. After that, determine the percentage of teachers in each category namely: very familiar with HOTS- most familiarly, knowing HOTS-good familiarity, quite familiaradequate familiarity, not familiar with HOTS-less familiarity, and not familiar based on the criteria in Table 1. 
Table 1. Familiarity categories.

\begin{tabular}{|c|c|c|c|}
\hline \multirow{2}{*}{ Category } & \multicolumn{3}{|c|}{ Criteria } \\
\hline & Concept & Application & Total \\
\hline Most familiar & 5 & $4-5$ & $9-10$ \\
\hline Good familiar & 4 & $3-4$ & $7-8$ \\
\hline Adequate familiar & 3 & $2-3$ & $5-6$ \\
\hline Less familiar & 2 & $1-2$ & $3-4$ \\
\hline Not familiar & $0-1$ & $0-1$ & $0-2$ \\
\hline
\end{tabular}

Questionnaire data were analyzed using content analysis to clarify the familiarity of science teachers on HOTS. Based on the criteria of Table 1, the percentage of teachers in each category can be determined.

\section{Results and Discussion}

\subsection{Results}

Science teachers' familiarity with HOTS is shown in Figure 1, Table 2, and Table 3.

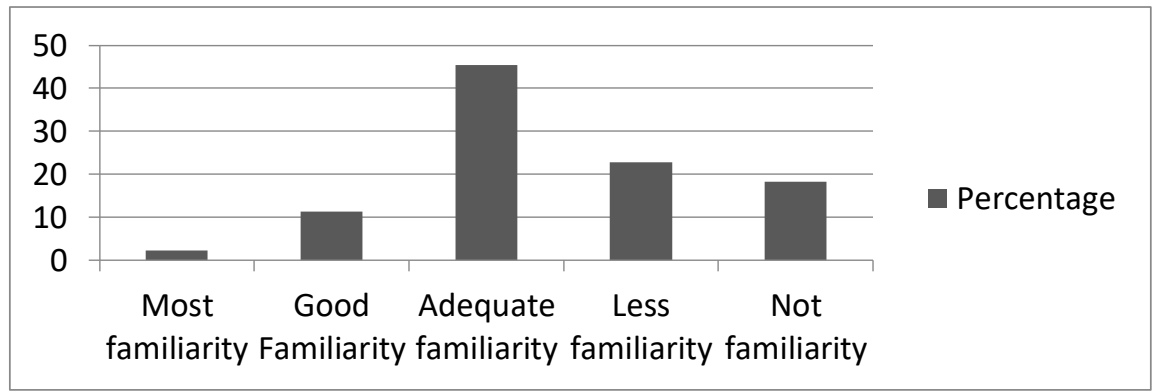

Fig. 1. Levels of HOTS familiarity of science teachers.

Figure 1 shows that more than $50 \%$ of science teachers are familiar with HOTS. Even though, there are still many teachers $(50 \%)$ who are still less familiar or not familiar enough with HOTS.

Table 2. Common Keywords to Represent Teachers' Familiarity on HOTS Concept.

\begin{tabular}{clcc}
\hline No. & Common keywords in HOTS concept & N & Percentage (\%) \\
\hline 1. & Recognizing hots skills & 9 & 20.45 \\
2. & Recognizing questions based HOTS & 25 & 56.82 \\
3. & Inquiry setting for HOTS & 31 & 70.45 \\
4. & Skills demand for HOTS & 19 & 43.18 \\
5. & Activities that involving HOTS & 28 & 63.64 \\
\hline
\end{tabular}


Based on Table 2, the science teachers are actually still having difficulty to distinguish the types of HOTS, such as creative thinking, evaluative thinking, and analytical thinking. However, more than $50 \%$ of teachers are able to recognize inquiry questions and activities that involve HOTS. In addition, less than $50 \%$ of teachers do not yet know the skills needed to operate HOTS.

Table 3. Common Keywords of HOTS' Application in Classroom.

\begin{tabular}{clcc}
\hline No. & HOTS Familiarity in the Science Classroom & N & Percentage (\%) \\
\hline 1. & Models of learning to train HOTS & 30 & 68.18 \\
2. & Starting learning to train HOTS & 42 & 95.45 \\
3. & Ending learning to train HOTS & 18 & 40.91 \\
4. & Designing experiment for HOTS & 32 & 72.73 \\
5. & Differentiating HOTS question & 32 & 72.73 \\
\hline
\end{tabular}

At the application stage, Table 3 shows that teachers are generally familiar with the activity of starting learning that can trigger HOTS. Even though, they are not familiar enough with activities that can trigger HOTS at the end of learning.

Table 4 shows that the majority of science teachers have to experience the learning models, such as PBL and cooperative which are contradicted to the fact that half of the science teachers have difficulty to explain the role of HOTS in science learning. More than $50 \%$ of teachers have difficulty to explain the methods used, even though they have used the HOTS model. It is surprising that more than $50 \%$ do not show curriculum bills or learning outcomes that are HOTS. The homework that was frequently given to students were not supported HOTS, such as: only classifying biotic or abiotic. Data in Table 4 also shows that the new teachers are limited to understanding HOTS terms and are still difficult to apply.

Table 4. Teachers' Experience in HOTS Training During Science Classroom.

\begin{tabular}{lccc}
\hline \multicolumn{1}{c}{ Questions Focus } & HOTS & Not HOTS & Undefinite \\
\hline Models of learning that are frequently used in course & 72.73 & 13.64 & 13.64 \\
Applying HOTS in science classroom & 47.73 & 15.91 & 36.36 \\
Training Method & 36.36 & 6.82 & 56.82 \\
Learning outcome & 27.27 & 0 & 70.45 \\
Students' homework & 9.09 & 25 & 68.18 \\
\hline
\end{tabular}

\subsection{Discussion}

Higher-order thinking skills or HOTS are urgently required to learn science. Students also need HOTS to live in the $21^{\text {st }}$ century. Unfortunately, students are not able to achieve it automatically without intensive practices [9], [12]. Therefore, the teacher has a very important role to facilitate their students to acquire higher-order thinking skills through courses [16]. Students have difficulty operating scientific thinking skills because teachers also are not able 
to think scientifically [12]. These findings indicate that teachers must be mastered in HOTS to facilitate students to acquire HOTS during the classroom.

This study is an early detection of teachers' familiarity concerning HOTS through a number of some common keywords or terms that are supposed to be familiar to the science teachers. They are most frequently encounter in the science classroom when implementing the 2013 curriculum. However, this study found that $45 \%$ of the science teachers are sufficiently familiar with HOTS, $11 \%$ are good familiarity, and only $2 \%$ of the teachers are most familiar with HOTS. A total number of $41 \%$ of the science teachers are not familiar with HOTS. The teachers' familiarity is further clarified to its application. In the context of learning, teachers, in general, are familiar with HOTS during starting learning in the orientation phase but are not apparent at the end. Despite $70 \%$ of teachers recognize learning models that stimulate HOTS, more than $50 \%$ of the teachers do not experience reflection activities at the final phase of course. From a training perspective, teachers generally still have difficulties, both in applying, differentiating learning outcomes, and tasks that stimulate HOTS. These facts are then confirmed to teachers' responses for clarification.

All teachers acknowledged attended HOTS training previously. However, it has never applied to learning. Table 4 shows that more than $50 \%$ of teachers are familiar with HOTS as a term, but have not been able to distinguish questions and learning designs that can stimulate students' higher-order thinking skills on science learning materials. These facts are supported by the previous study that most teachers could not explain HOTS apply in their classroom [14]. It is impossible for students to be trained to operate HOTS in learning. Teachers' difficulty performing HOTS impacted students in operating HOTS during learning processes [12]. Judging from Bybee's classification concerning science literation, the science teachers have only reached the functional level who only knew terms especially related to inquiry learning, but did not yet have a conceptual understanding (Table 2). Learning activities, especially inquiry that stimulates HOTS are well known to teachers, but operationally it is not well understood. At this level, the teacher might not be able to train students' HOTS thinking optimally. Therefore, it is important to prepare and train teachers in mastering HOTS both concepts and their applications in learning are still very much needed [15],[16].

\section{Conclusion}

Science teachers are generally quite familiar with HOTS terms especially those related to inquiry learning activities, but conceptually are still less familiar. Teachers' familiarity with HOTS is only limited to terms or vocabulary. It is potentially to have a misunderstanding of HOTS because it has not yet reached the conceptual category and may not be able to apply in the classroom. Thus, science teachers are not ready to facilitate students acquiring higherorder thinking skills during learning. Mastering HOTS conceptually and in application among science teachers are urgently required.

\section{References}

[1] Erman, E.: Encouraging Student's Formal Thinking Ability Through Early Science Learning. Elementary Education Journal, 5, 92 - 101 (2004)

[2] Johnstone, A.H.: Why is Science Difficult to Learn? Things are Soldom What They Seem. Journal of Computer Assisted Learning, 7, 75-83 (1991) 
[3] Martini \& Erman, E.: The constructivist Intervention in Biochemical Course Material to Train Students Understand Abstract Concepts (Unpublication Research Report). Surabaya: LPPM Unesa (2009)

[4] Santoso, T., Yuanita, L. \& Erman, E.: The role of students' critical asking questions in developing students' critical thinking skills. Journal of Physics: Conference Series 953 (2017) 012042. Doi. 10.1088/1742-6596/953/1/012042 (2017)

[5] Eshach, H., Ziderman, Y.D., \& Yefoinsky, Y.: Quaetion asking in the science classroom: teacher attitudes and practices. Journl of Science Education Technology, 67-81 (2014)

[6] Resnick, L.B.: Education and learning to think. Washington DC: National Academic Press (1987)

[7] Bybee, R.W.: Achieving scientific literacy: from purposes of practices. Portsmouth: NH Heinmann Publishing (1997)

[8] Darwish, A.H.: The Abstract Thinking Levels of the Science-education Students in Gaza Universities. Asia-Pacific Forum on Science Learning and Teaching, 15(2), 1-24 (2013)

[9] Herron, J.D.: Piaget for Chemist; Explaining What Good Student Cannot Understand, Journal of Chemical Education, 52, 146 - 150 (1975)

[10] Karplus, R.: Science Teaching and The Deveploment of Reasoning, Journal of Research in Science Teaching, 14, 169 - 175 (1977)

[11] Shayer, M. \& Adey, P.S.: Accelerating The Development of Formal Thinking in Middle and High School Student IV: Three Years after a Two-Year Intervention, Journal of Research in Science Teaching, 30, $351-366$ (1993)

[12] Wooley, J.S., Deal, A.M., Green, J., Hathenbruck, F., Kurtz, S.A., Park, T.K.H., Pollock, S.V., Transtrum, M.B., \& Jensen, J.L.: Undergraduate Students Demonstrate Common False Scientific Reasoning Strategies. Thinking Skills and Creativity, 27, 101-113 (2018)

[13] Zimmerman, C.: The development of scientific thinking skills in elementary and middle school. Developmental Review, 27, 172-223 (2007)

[14] Retnawati, H., Djidu, H., Kartianom, Apino, E., \& Anazifa, R.D.: Teachers' knowledge about high order thinking skills and its learning strategy. Problem of Education in the $21^{\text {st }}$ Century, 76,2 (2018)

[15] Gibson, M.: Integrating high-order thinking skills into the L2 classroom. (in Breeze, R., Jimeneze Berrio, F., Liamas Saiz, C., Martinez Pasamar, C., y Tabernero Sala, C. (eds.) (2012): Teaching Approaches to CLIL/Propuestas docentes en AICLE, Pamplona: Servicio de Publicaciones de la Universidad de Navarro (2012)

[16] Hasyim, T., Osman, R., Arifin, A., Abdullah, N., Noh, N.M.,: Teachers perceptions on high order thinking skills as an innovation and its implementation in history teaching. Australian Journal of Basic and applied science, 9(32): 215-221 (2015) 